\title{
Comparing the quality of services by public and private banks in the view of customers
}

\author{
Zolfa Haghgooyan, Gholamreza Jandaghi, Leyli Sharifi \\ Postgraduate, Faculty of Management and Accounting, Farabi College, University of Tehran, Iran \\ E-mail address: jandaghi@ut.ac.ir
}

Keywords: service quality; Reliability; Tangibility; Responsiveness; Assurance; Empathy

\begin{abstract}
Present paper aims at studying and comparing the quality of services by public and private banks of Qom Province in the view of customers. This is an applied study and it is a descriptive survey in terms of data collection method. Its population consists of customers of Qom Province public and private banks, SERVQUAL standard model is used in present study. It includes five aspects: Reliability, Tangibility, Responsiveness, Assurance and Empathy.

To study the quality of services and their aspects in public and private banks, single population average test is used while two - population average test is utilized to compare the quality of services in private and public banks. The results from single population average tests indicate that the status of service quality and the aspects of SERVQUAL are desired in both Qom Province private and public banks. Likewise, the results for two - population average tests reveal that provided services by both public and private banks have similar quality and there is no difference between them in this regard. Concerning the SERVQUAL model, the findings indicate that physical environment of private banks is better than public peers. However, there is no difference between them in other aspects.
\end{abstract}

\section{INTRODUCTION}

Service quality has been a frequently studied topic in the service marketing literature. Efforts to understand and identify service quality have been undertaken in the last three decades (Kang \& James, 2004).

The improvement of service quality has become a major strategy for improving competitiveness. The identification of customers' requirements and the measurement of satisfaction levels are therefore two crucial activities for enterprises. However, firms frequently fail to understand customer requirements, and the usual methods for measuring customer satisfaction are incomplete. From the beginning of the 1980 s, quality awareness and customer consciousness have been growing steadily. As a result, enterprises have not only been seeking business growth and an improved competitive position, but have also been devoting themselves to upgrading "quality".

Along with this, service "quality" has also received significant attention. It is well known that improved service quality enhances productivity and reduces costs, as well as increasing customer loyalty, market share, and general benefits for the company. Most enterprises are therefore using service quality as a key weapon in seeking competitive edge (Yang, 2003). In market - based economy, banking system is an important component and constitutes an important part of service industry. Today, banks have no choice than paying special attention to their service quality to compete in turbulent environment. Therefore, the hyper competitive and changing environment where banks have to operate has caused them to revise their views on customer satisfaction and optimizing the quality of their services. Many companies have found that providing continuous services with superior quality than rival can bring them a powerful competitive advantage (Hassan Husseini and Ghaderi, 2010).

A topic of particular interest in service quality research is the issue of measurement. Following the introduction of the SERVQUAL instrument, many scholars have attempted to replicate and refute its structure and conceptualization (Kang \& James, 2004). Much of the 
research to date has focused on measuring service quality using the SERVQUAL instrument (Kang \& James, 2004). SERVQUAL model investigates service quality in five aspects which include: Tangibility, Reliability, Assurance, Responsiveness and Empathy (Ghalvandi et al, 2012).

Concerning privatization growth in the country to execute article 44 of the Constitutional Law and privatizing public banks, the main aim of present paper is to compare service quality of private and public banks in Qom Province.

\section{SERVICE QUALITY}

Scholars have defined the service concept in many different ways. Most often activities, deeds, processes and interactions are used when defining the concept of service (Edvardsson, 2005). The construct of quality in the services literature focuses on perceived quality, which is defined as a consumer's judgment about an entity's overall excellence or superiority (Kang, 2006). This approach differs from that of objective quality, which involves an objective assessment of a thing or event. Perceived quality is a form of "attitude", resulting from a comparison of expectations with perceptions of performance. However, despite the emphasis in the literature on this approach, perceived service quality has remained an elusive concept (Kang, 2006).

From a fulfillment-oriented perspective, service quality is defined as the capability to meet and exceed the results that the provider and the customer mutually defined and embraced at the beginning of a service encounter. The disconfirmation paradigm for this approach is given below:

Service quality $=$ [Quality of delivered "agreed" results + Quality of delivered "unexpected" results - Quality loss due to undelivered "agreed" results - Quality loss due to delivered "unexpected" damages]/Quality of all "agreed" results (under ideal conditions).

Where:

Quality of all "agreed" results (under ideal conditions) $=$ [Quality of delivered "agreed" results + Quality loss due to undelivered

"agreed" results].

Agreed results $=$ positive and meaningful outcomes that customers need, appreciate, and mutually agreed to at the beginning of the process.

éU = Quality of the positive and meaningful outcomes that customers need and appreciate but did not expressly demand or request (delivered unexpected results) (Dedeke,2003).

Overall, one can say that a service is qualitative when it can meet customers' needs and can be adapted to customers' expectations (Moradi and Hemati, 2010).

\section{DIMENSIONS OF SERVICE QUALITY}

Whereas service quality is known to be based on multiple dimensions, there is no general agreement as to the nature or content of the dimensions. Lehtinen and Lehtinen (1982) defined service quality in terms of physical quality, interactive quality and corporate (image) quality. Physical quality relates to the tangible aspects of the service. Interactive quality involves the interactive nature of services and refers to the two-way that occurs between the customer and the service provider, or his/her representative, including both automated and animated interactions. Corporate quality refers to the image attributed to a service provider by its current and potential customers, as well as other publics. Gro"nroos (1982) identified two service quality dimensions, the technical aspect ("what" service is provided) and the functional aspect ("how" the service is provided). The customers perceive what $\mathrm{s} / \mathrm{he}$ receives as the outcome of the process in which the resources are used, i.e. the technical or outcome quality of the process. But s/he also and often more importantly, perceives how the process itself functions, i.e. the functional or process quality dimension. Gro"nroos also emphasized the importance of corporate image in the experience of service quality, similar to the idea proposed by Lehtinen and Lehtinen (1982). Customers bring their earlier experiences and overall perceptions of a service firm to each encounter because customers often have continuous contacts with the same service firm (Kang \& James, 2004). 
Dabholkar et al. (1996), where they conceptualize service quality in the more general retail industry:

Dimension 1: Personal interaction with the customer.

Dimension 2: Reliability of service delivery to the customer.

Dimension 3: Problem solving for the customer.

Dimension 4: Policy issues with respect to the customer.

Dimension 5: Physical aspects of the relationship with the customer.

(Blose and Tankersley, 2004)

A more recent conceptualization of the service quality dimensions was proposed by Rust and Oliver (1994). They proposed a three-component model in which the overall perception of service quality is based on a customer's evaluation of three dimensions of the service encounter:

(1) The customer-employee interaction (i.e. functional or process quality),

(2) The service environment, and

(3) The outcome (i.e. technical quality) (Kang \& James, 2004).

Lovelock (2000) adopted a multi-factorial view of service quality in talking about:

. The marketing imperative of service quality;

. The operations imperative of service quality; and

. The human-resources imperative of service quality

Kemp (2005) has identified five dimensions to sustainability:

1. Ethical dimension. The ethical dimension is based on the moral relationship between the societies of today and those that will follow. The ethical dimension refers to whether future generations will praise or condemn the actions of today. This idea was also a central argument of the Brundtland (1987) report.

2. Social dimension. The focus of the social dimension is on social justice and the need to attend to social justice in the present, rather than putting it off until tomorrow.

3. "Nature-philosophic" dimension. The "nature-philosophic" dimension is based on the presumption that nature is vulnerable and that there are limits to the degree of interference that nature can bear before future generations will be affected by problematic living conditions.

4. Economic dimension. The economic dimension is predicated on awareness that "sustainable development" requires sound economic theory and practice.

5. Legal dimension. The legal dimension encapsulates human rights in all aspects of human life (Kemp, 2005). Two legal strategies drive sustainable progress: civil regulation; and government regulation (Enquist \& et al, 2007).

Finally Chang and Chelladurai (2003) used confirmatory factor analysis and a survey of American fitness club members to develop a nine-dimensional scale of fitness-service quality:

(1) "Service climate".

(2) "Management commitment to service quality".

(3) "Programming".

(4) "Personal interaction".

(5) "Task interaction".

(6) "Other clients".

(7) "Service failure".

(8) "Service recovery".

(9) "Perceived service quality".

(Lagrosen \& Lagrosen, 2007)

\section{SERVQUAL}

Although there is low concurrence on studying and identifying affecting factors on service quality in the views of customers (Moradi and Hemati, 2010) and barriers such as the impossibility of separating service from servicer and its time and location have made quality dependency to more ambiguous cases and its measurement more complicated (Rajabipour Meybodi \& Rajabipour Meybodi, 2010). However, there are different models to evaluate service quality such Cano, 
SERVQUAL, QFD and others. In present study, SERVQUAL model is used to compare service quality in Qom province public and private banks. In literature, SERVQUAL is among the strongest and most applied models to evaluate service quality (Anvari Rostami et al, 2005). It was devised by Parasuraman, Zeithamel and Barry (1990) as the most reputable tool to measure service quality (Zahedi, 2011).

They ultimately condensed these into five factors or service-quality dimensions:

Tangibility: it includes facilities and equipment and communicational merchandises. All these create an image considered by customer to assess quality such amenities in organization's physical environment.

Reliability: it means the ability to conduct services in a trustworthiness manner so that customers' expectations are met. In fact, reliability is to meet the commitments; namely, if the organization gives promises on the ways and costs of providing services, it should make them practically.

Responsiveness: it means disposition to cooperate and support customers. It emphasizes on sensitiveness and smartness on demands questions and complaints of customers.

Assurance: it guarantees employees' competencies in inspiring the feeling of trust by customer to organization. It is especially important in services with higher risks.

Empathy: it means personal attention and allocating proper working time to all customers namely, treat each customer uniquely based on his/her moods so that the customers are convinced that the organization has conceived them and they are important for the organization (Ghalvandi et al, 2012).

Each dimension is measured by four to five items (making a total of 22 items across the five dimensions). Each of these 22 items is measured in two ways:

(1) The expectations of customers concerning a service; and

(2) The perceived levels of service actually provided.

(Ladhari, 2008)

SERVQUAL is based on the "gap model" of service quality, which defines service quality as a function of the "gap" between customers' expectations of a service and their perceptions of the actual service delivered (Yang, 2003). The ultimate aim of the model is to navigate organization toward performance excellence (Mirghafouri and Zare Ahmadabadi, 2007).

\section{BACKGROUND}

Here, three studies on the service quality by banks are pointed out and then other studies on identifying the aspects of service quality and measuring them in other environments are provided.

A research is conducted to identify affecting factors on banking service quality. In this line, upon two steps of distributing questionnaires and analyzing the results, 50 indicators were identified as the most important affecting factors on banking service quality. Upon inserting them in final questionnaire and distributing it, factor analysis method was used to analyze information and to mitigate variables. The findings from factor analysis indicate that over $65 \%$ of variances in variables are justified by 9 factors and remained $35 \%$ by other ones which were not measured. As a result, 9 factors were identified as the most important affecting factors on banking service quality. In terms of importance, they include: employees' behavior; employees' competency and skills; innovation in banking services; interest and facilities; responsiveness and providing banking services; physical facilities; trustworthiness' diversity and facility in services (Hassan Husseini and Ghaderi, 2010).

A study was conducted to determining affecting factors on banking service quality in Refah Bank. To this end, scientific well - known literature, elite's opinions and academic/banking connoisseurs were used. To study the importance of components, the viewpoints of a sufficient sample $f$ bank customers and employees were gathered and analyzed. Statistical results indicated a significant difference between the views of customers and employees on the relative importance of quality components. On the other hand, the results of analyses express a significant difference between prioritizing modifying initiatives of customers and employees to improve service quality. Below, four models are used to determine and evaluate the quality of banking services in Refah Bank: normal and weighted SERVQUAL, SERVPROV and SERVIMPROV. 
The results of quantitative mathematical calculations and statistical analyses show that:

1. In all four models, both customers and employees have evaluated banking service quality higher than average.

2. In all four models and in contrary to general opinions, employees have given lower scores to the service quality of their own bank.

3. The results of quality evaluations by four models indicate significant stability in results (Anvari Rostami et al, 2005).

In present study which is the result of a field study, the aspects of banking services by Mellat Bank branches in Isfahan Province and the amount of people's satisfaction are studied. A questionnaire with closed questions was distributed to measure the aspects of banking service quality and customer satisfaction. SERVQUAL model is used to measure customer satisfaction. Its methodology is a descriptive survey. Research findings indicate that four aspects of reliability, responsibility, guarantee and empathy impact on customer satisfaction while appearance and physical conditions have no impact on customer satisfaction from service quality (Ziviar et al, 2012).

Study sought to develop a customer-perceived market orientation called service-driven market orientation (SERVMO) and examined its relationship with customer-perceived service quality in a higher education setting. This new market orientation construct is believed to be potentially important for more effective and efficient service quality management. The 32-item multidimensional SERVMO construct is found to be a valid and reliable measure that is relatively comprehensive, comprising six (6) multi-item components: customer orientation, competitor orientation, inter-functional orientation, performance orientation, long-term orientation, and employee orientation. The findings clearly suggest that there is a strong and positive relationship between the proposed SERVMO and service quality. Its effects on the different dimensions of SERVQUAL are also significantly strong and positive. Moreover, all the SERVMO components are found to be impactful on customer-perceived service quality, with the employee orientation being the most dominant factor. (Voon, 2006)

Oliver (1980) empirically demonstrated that attitude was a superordinate concept of satisfaction. Cronin and Taylor (1992) investigated the path between satisfaction and service quality using a sample of eight service firms from four service sectors. They verified a significant path from satisfaction to quality, but not a significant connection in the reverse direction. This finding suggests that customers might not always be dissatisfied with poor quality, whereas they are not always satisfied with excellent quality. A study by Cronin et al. (1997) of six services industries concluded that the addition of the item of service value to the construct of service quality predicted the purchase intentions of customers. In her study of two banks, Clark (1997) concluded that improved service quality and customer satisfaction contributed to increased customer retention. This bond between customer and service offering or service provider is also called "loyalty" or "attachment". Heskett et al. (1990) and Bolton and Drew (1991) also concluded that service quality is linked to service value. Rust and Oliver (1994) concluded that perceived costs influenced service value. (Dedeke, 2003).

A study concerns with the purpose of identifying differences in the management of quality between manufacturing, private service and public service organizations' questionnaire was sent to members of the Swedish Association for Quality. Some interesting differences were identified. Customer orientation is highest in the private service sector and lowest in the public service sector. The manufacturing companies' usage of ISO 9000 is extremely high and their usage of the Swedish Quality Award is fairly low whereas the public service organizations use both these two models equally. This corresponds with the finding that ISO 9000 produces better results in the manufacturing sector whereas The Swedish Quality Award produces better results in the service sector. Generally, the indication is that quality management is most successful in the manufacturing sector and least successful in the public service sector. There is also a difference in that improvements in the manufacturing sector are more often about the processes whereas the organizations within the public service sector more often report improvements regarding personnel (Lagrosen and Lagrosen, 2003). 


\section{Research major aims:}

1. Studying the status of service quality in Qom public banks in the view of customers

2. Studying the status of service quality in Qom private banks in the view of customers

3. Comparing the status of service quality between Qom public and private banks

Minor aims

1. Comparing tangibility in Qom public and private banks

2. Comparing Reliability in Qom public and private banks

3. Comparing Responsiveness in Qom public and private banks

4. Comparing Assurance in Qom public and private banks

5. Comparing Empathy in Qom public and private banks

\section{Research major questions}

1. How is the service quality status in Qom public banks in the view of customers?

2. How is the service quality status in Qom private banks in the view of customers?

3. Is there any difference on the quality of provided services to customers in Qom private and public banks?

\section{Minor questions}

1. Is there any difference on the tangibility in Qom private and public banks?

2. Is there any difference on the Reliability in Qom private and public banks?

3. Is there any difference on the Responsiveness in Qom private and public banks?

4. Is there any difference on the Assurance in Qom private and public banks?

5. Is there any difference on the Empathy in Qom private and public banks?

\section{METHODOLOGY}

In terms of aims, researches are exploratory, descriptive or hypothesis testing. Exploratory studies are important to understand problem nature better and to expand knowledge through theorizing while descriptive studies are conducted to determine and to describe the changing traits of a situation. Those studies conducted to test hypotheses are often clarifying special relations or determining current differences between groups or lack of correlation between two or more factors in the same situation (Skaran, Uma, 2012: 120 - 127). In terms of purpose, this is descriptive study. On the other hand, scientific studies are divided into experimental and non-experimental researches (Yazdani, 2012: 160). On this basis, present paper is considered as a non-experimental one since data gathering is natural and without any manipulation.

In terms of time horizons, researches are either cross - sectional or linear. Some studies are conducted so that their data is gathered one time to answer research question. They are called single, cross - sectional or latitudinal while in linear studies, researcher studies on phenomena or individual in several intervals (Skaran, Uma, 2012: 141 - 142).

In present study, since data is gathered one time, it is a cross - sectional study in terms of time horizon

\section{Population, quantity and sampling method}

Research population refers to all individuals, events or things the author plans to study them (Amaskaran, 2012: 294). Research population consists of all Qom Province public and private banks' customers. Selected public and private banks are shown in table 1. 
Table 1: Sample size in terms of banks

\begin{tabular}{|c|c|c|c|}
\hline Branches & Public banks & Branches & Private banks \\
\hline Tarehbar, Sadooghi & Sepah & Bazaar & Eghtesad novin \\
\hline Qom & Post Bank & Qom & Parsian \\
\hline Jihad, Shoahda, Alghadir & Melli & Qom & Karafarin \\
\hline Qom & $\begin{array}{c}\text { Export } \\
\text { development }\end{array}$ & Qom & Saman \\
\hline Qom & $\begin{array}{c}\text { Industry \& } \\
\text { Mine }\end{array}$ & Qom & Pasargad \\
\hline $\begin{array}{c}\text { Tarehbar, Safaei, Amin } \\
\text { Boulevard, Qom }\end{array}$ & Keshavarzi & Amin Boulevard & Sarmayeh \\
\hline $\begin{array}{l}\text { Enghelab, Markazi, Tohid, } \\
\text { Shohada }\end{array}$ & Maskan & Sadooghi & Sina \\
\hline \multirow[t]{10}{*}{ Masoumieh } & Tosee Taavon & Salariyeh & Shahr \\
\hline & & Qom & Day \\
\hline & & Imam Khomeini & Ansar \\
\hline & & $\begin{array}{l}\text { Haft-e-Tir, Bonyad, Amin } \\
\text { Boulevard, Markazi }\end{array}$ & Tejarat \\
\hline & & $\begin{array}{l}\text { Masoumieh, Azar, Amin } \\
\text { Boulevard, Markazi }\end{array}$ & Refah \\
\hline & & $\begin{array}{l}\text { Razavieh, Imamzadeh } \\
\text { Ebrahim, Qom, Imam }\end{array}$ & Saderat \\
\hline & & $\begin{array}{c}\text { Jihad, Keyvanfar, Markazi, } \\
\text { Amin Boulevard }\end{array}$ & Mellat \\
\hline & & Qom & Hekmat Iranian \\
\hline & & Shahid Fatemi & Iran Zamin \\
\hline & & Amin Boulevard & Ghavamin \\
\hline
\end{tabular}

Since population is unlimited, unlimited population sampling formulation is used. By error level of 0.1 (confidence level of $90 \%$ ) and average difference of 0.35 , sample size is 200 for each private and public banks. In other words, totally 404 questionnaires were distributed among Qom private and public banks' customers.

\section{Data collection tool}

Overall, data collection tools are divided into two categories: library and field study. In present study, both techniques are utilized. Below sources are needed to gather information:

- $\quad$ Studying library documents

- Internet websites and portals

- $\quad$ Books and papers in both Persian and English

Theoretical literature and background were studied by using past researches including library studies such as books, papers and relevant websites. SERVQUAL model is used to collect data. Since this questionnaire is severally used in Iran and its validity is confirmed, 30 questions of the questioner were inserted into SPPS software package and Cronbach's alpha value $(0.85)$ indicates that it enjoys necessary reliability $(\alpha>0.70)$. in present study, to analyze the information, inductive statistics including single population test is used to examine service quality of public and private banks while two - population independent test is used to compare service quality of private and public banks in SPSS software package.

\section{Findings}

To answer the main $1^{\text {st }}$ question (how is service quality in Qom public banks in the view of customers), single population average test is used. The results are shown in tables 2 and 3. 
Table 2: Single population average statistics on service quality of public banks

\begin{tabular}{|c|c|c|c|c|}
\hline \multicolumn{5}{|c|}{ One-Sample Statistics } \\
\hline Variables & $\mathrm{N}$ & Mean & Std. Deviation & Std. Error Mean \\
\hline Tangibility & 192 & 3.1920 & .67599 & .04879 \\
\hline Reliability & 192 & 3.3013 & .65636 & .04737 \\
\hline Responsiveness & 192 & 3.1737 & .68692 & .04957 \\
\hline Assurance & 192 & 3.3635 & .71644 & .05170 \\
\hline Empathy & 192 & 3.1903 & .73967 & .05338 \\
\hline Service Quality & 192 & 3.2442 & .60054 & .04334 \\
\hline
\end{tabular}

Table 3: The results of single population average test on service quality of public banks

\begin{tabular}{|c|c|c|c|c|c|c|}
\hline \multirow{2}{*}{ Variables } & \multicolumn{7}{|c|}{ One-Sample Test } \\
\cline { 2 - 7 } & $\mathrm{t}$ & $\mathrm{df}$ & Sig. (2-tailed) & Mean Difference & \multicolumn{2}{c|}{$\begin{array}{c}\text { 95\% Confidence Interval of the } \\
\text { Difference }\end{array}$} \\
\cline { 3 - 8 } & & & & & Lower & Upper \\
\hline Tangibility & 3.936 & 191 & .000 & .19201 & .0958 & .2882 \\
\hline Reliability & 6.360 & 191 & .000 & .30128 & .2078 & .3947 \\
\hline Responsiveness & 3.504 & 191 & .001 & .17370 & .0759 & .2715 \\
\hline Assurance & 7.031 & 191 & .000 & .36354 & .2616 & .4655 \\
\hline Empathy & 3.564 & 191 & .000 & .19028 & .0850 & .2956 \\
\hline Service Quality & 5.634 & 191 & .000 & .24416 & .1587 & .3296 \\
\hline
\end{tabular}

$\mathrm{H}_{0}$ is confirmed if test significance value is greater than significance level (0.05). It means that the variable (3) is in medium level. $\mathrm{H}_{0}$ is not confirmed if test significance value is less than significance level. We should pay attention to upper and lower level symbols to decide on greater or lesser than average value (3). If both symbols are negative, the variable is lower than medium level (3). If both symbols are positive, the variable is greater than medium level (3).

As seen in table 3, T-Test results indicate that service quality by Qom public banks are in desired level (last column in table 3). Likewise, SERVQUAL aspects including Reliability, Tangibility, Responsiveness, Assurance, and Empathy are desired in Qom public banks.

To answer the main $2^{\text {nd }}$ question (how is service quality in Qom private banks in the view of customers), single population average test is used. The results are shown in tables 4 and 5.

Table 4: Single population average statistics on service quality of public banks

\begin{tabular}{|c|c|c|c|c|}
\hline \multicolumn{5}{|c|}{ One-Sample Statistics } \\
\hline Variables & $\mathrm{N}$ & Mean & Std. Deviation & Std. Error Mean \\
\hline Tangibility & 212 & 3.3498 & .75650 & .05196 \\
\hline Reliability & 212 & 3.2473 & .75537 & .05188 \\
\hline Responsiveness & 212 & 3.1761 & .81039 & .05566 \\
\hline Assurance & 212 & 3.3635 & .74309 & .05104 \\
\hline Empathy & 212 & 3.1418 & .84602 & .05811 \\
\hline
\end{tabular}




\begin{tabular}{|c|c|c|c|c|}
\hline \multicolumn{5}{|c|}{ One-Sample Statistics } \\
\hline Variables & $\mathrm{N}$ & Mean & Std. Deviation & Std. Error Mean \\
\hline Tangibility & 212 & 3.3498 & .75650 & .05196 \\
\hline Reliability & 212 & 3.2473 & .75537 & .05188 \\
\hline Responsiveness & 212 & 3.1761 & .81039 & .05566 \\
\hline Assurance & 212 & 3.3635 & .74309 & .05104 \\
\hline Empathy & 212 & 3.1418 & .84602 & .05811 \\
\hline Service Quality & 212 & 3.2557 & .66134 & .04542 \\
\hline
\end{tabular}

Table 5: The results of single population average test on service quality of public banks

\begin{tabular}{|c|c|c|c|c|c|c|}
\hline \multicolumn{7}{|c|}{ One-Sample Test } \\
\hline \multirow{3}{*}{ Variables } & \multicolumn{6}{|c|}{ Test Value $=3$} \\
\hline & \multirow[t]{2}{*}{$\mathrm{t}$} & \multirow[t]{2}{*}{$\mathrm{df}$} & \multirow[t]{2}{*}{ Sig. (2-tailed) } & \multirow[t]{2}{*}{ Mean Difference } & \multicolumn{2}{|c|}{$\begin{array}{l}\text { 95\% Confidence Interval of the } \\
\text { Difference }\end{array}$} \\
\hline & & & & & Lower & Upper \\
\hline Tangibility & 6.732 & 211 & .000 & .34976 & .2473 & .4522 \\
\hline Reliability & 4.767 & 211 & .000 & .24730 & .1450 & .3496 \\
\hline Responsiveness & 3.164 & 211 & .002 & .17610 & .0664 & .2858 \\
\hline Assurance & 7.123 & 211 & .000 & .36352 & .2629 & .4641 \\
\hline Empathy & 2.441 & 211 & .015 & .14182 & .0273 & .2564 \\
\hline Service Quality & 5.630 & 211 & .000 & .25570 & .1662 & .3452 \\
\hline
\end{tabular}

As seen in table 5, T-Test results indicate that service quality by Qom private banks are in desired level (last column in table 5). Likewise, SERVQUAL aspects including Reliability, Tangibility, Responsiveness, Assurance, and Empathy are desired in Qom private banks.

To answer the main $3^{\text {rd }}$ question (Is there any difference on the Responsiveness in Qom private and public banks?) and sub-questions, two - population independent average test single population average test is used. The results are shown in table 6.

Table 6: The results of two - population independent average test on service quality of private and public banks in the view of their customers

\begin{tabular}{|c|c|c|c|c|c|c|c|c|c|c|}
\hline \multicolumn{11}{|c|}{ Independent Samples Test } \\
\hline & & $\begin{array}{r}\text { Lev } \\
\text { Tes } \\
\text { Equa } \\
\text { Vari }\end{array}$ & $\begin{array}{l}\text { ne's } \\
\text { for } \\
\text { ty of } \\
\text { ices }\end{array}$ & \multicolumn{7}{|c|}{ t-test for Equality of Means } \\
\hline \multirow[t]{2}{*}{ Variables } & & \multirow[t]{2}{*}{$\mathrm{F}$} & \multirow[t]{2}{*}{ Sig } & \multirow[t]{2}{*}{$\mathrm{t}$} & \multirow[t]{2}{*}{ Df } & \multirow{2}{*}{$\begin{array}{l}\text { Sig. } \\
(2- \\
\text { tailed })\end{array}$} & \multirow[t]{2}{*}{$\begin{array}{c}\text { Mean } \\
\text { Difference }\end{array}$} & \multirow[t]{2}{*}{$\begin{array}{l}\text { Std. Error } \\
\text { Difference }\end{array}$} & \multicolumn{2}{|c|}{$\begin{array}{l}95 \% \text { Confidence } \\
\text { Interval of the } \\
\text { Difference }\end{array}$} \\
\hline & & & & & & & & & Lower & Upper \\
\hline \multirow{2}{*}{ Tangibility } & $\begin{array}{c}\text { Equal variances } \\
\text { assumed }\end{array}$ & \multirow{2}{*}{1.757} & \multirow{2}{*}{.186} & -2.201 & 402 & .028 & -.15775 & .07167 & -.29864 & -.01686 \\
\hline & $\begin{array}{c}\text { Equal variances } \\
\text { not assumed }\end{array}$ & & & -2.213 & 401.930 & .027 & -.15775 & .07127 & -.29786 & -.01764 \\
\hline \multirow[t]{2}{*}{ Reliability } & $\begin{array}{c}\text { Equal variances } \\
\text { assumed }\end{array}$ & \multirow{2}{*}{3.115} & \multirow{2}{*}{.078} & .763 & 402 & .446 & .05397 & .07074 & -.08509 & .19304 \\
\hline & $\begin{array}{c}\text { Equal variances } \\
\text { not assumed }\end{array}$ & & & .768 & 401.325 & .443 & .05397 & .07025 & -.08413 & .19208 \\
\hline
\end{tabular}




\begin{tabular}{|c|c|c|c|c|c|c|c|c|c|c|}
\hline \multirow[t]{2}{*}{ Responsiveness } & $\begin{array}{l}\text { Equal variances } \\
\text { assumed }\end{array}$ & \multirow{2}{*}{6.762} & \multirow{2}{*}{.010} & -.032 & 402 & .975 & -.00240 & .07514 & -.15012 & .14532 \\
\hline & $\begin{array}{l}\text { Equal variances } \\
\text { not assumed }\end{array}$ & & & -.032 & 400.279 & .974 & -.00240 & .07453 & -.14893 & .14412 \\
\hline \multirow{2}{*}{ Assurance } & $\begin{array}{l}\text { Equal variances } \\
\text { assumed }\end{array}$ & \multirow{2}{*}{.010} & \multirow{2}{*}{.920} & .000 & 402 & 1.000 & .00002 & .07278 & -.14306 & .14310 \\
\hline & $\begin{array}{l}\text { Equal variances } \\
\text { not assumed }\end{array}$ & & & .000 & 400.418 & 1.000 & .00002 & .07265 & -.14280 & .14284 \\
\hline \multirow[t]{2}{*}{ Empathy } & $\begin{array}{l}\text { Equal variances } \\
\text { assumed }\end{array}$ & \multirow{2}{*}{3.652} & \multirow{2}{*}{.057} & .610 & 402 & .542 & .04845 & .07943 & -.10769 & .20460 \\
\hline & $\begin{array}{l}\text { Equal variances } \\
\text { not assumed }\end{array}$ & & & .614 & 401.511 & .540 & .04845 & .07890 & -.10666 & .20357 \\
\hline \multirow{2}{*}{ Service Quality } & $\begin{array}{c}\text { Equal variances } \\
\text { assumed }\end{array}$ & \multirow{2}{*}{1.963} & \multirow{2}{*}{.162} & -.183 & 402 & .855 & -.01154 & .06308 & -.13555 & .11247 \\
\hline & $\begin{array}{l}\text { Equal variances } \\
\text { not assumed }\end{array}$ & & & -.184 & 401.997 & .854 & -.01154 & .06278 & -.13496 & .11188 \\
\hline
\end{tabular}

According to two - population average test (table 6), the outcome of the test is divided into two parts: the equality of variances in both groups and the results of testing the average of both groups in two conditions of variances equality and inequality. Significance ratio on Levin test (testing variances comparisons) is greater 0.05. Therefore, hypothesis on variance equality is supported. Studying the first sentence reveals that significance ratio on testing variances by hypothesizing variance equality is greater than 0.05 for service quality (last row in table 6). Therefore, we conclude that provided services by private and public banks enjoy equal quality in the view of customers (answering question 3 ).

One can answer minor questions by using table 6. As seen in the table, concerning physical environment, private and public banks are not equal (answering to minor question 1) since the significance ratio is smaller than 0.05 . Concerning table 2 and 4 , we conclude that the quality of physical environment of private banks is better public banks. Concerning Reliability, Responsiveness, Assurance, Empathy, (minor questions $2-5$ ), both private and public banks are equal since the relevant significance ration is greater than 0.05 .

\section{CONCLUSION}

Present paper aims at studying and comparing the quality of services by public and private banks of Qom Province in the view of customers. SERVQUAL standard model is used in present study. It includes five aspects: Reliability, Tangibility, Responsiveness, Assurance, and Empathy. The findings indicate that private and public banks are similar in their service quality and there is no difference in this regard. Concerning the aspects of SERVQUAL model, the results indicated that physical environment of private banks has better quality than public ones. Concerning other aspects of SERVQUAL model, there is no difference between private and public banks.

\section{References}

[1] Anvari Rostami, Ali Asghar; Torabi, Maryam \& Mohammadlu, Moslem Ali (2005), a comparative study of banking service quality in the views of customers and employees, Human Science Quarterly, pp. $53-64$

[2] Blose, Julia E. and Tankersley, William B.,(2004), "Linking dimensions of service quality to organizational outcomes”, Managing Service Quality, Volume 14,Number 1, pp. 75-89

[3] Dedeke, Adenekan,(2003), "Service quality: a fulfillment-oriented and interactions-centered approach", Managing Service Quality, Volume 13,Number 4, , pp. 276-289

[4] Edvardsson, Bo,(2005), "Service quality: beyond cognitive assessment", Managing Service Quality, Vol. 15,No. 2,pp. 127- 131

[5] Enquist, Edvardsson and Sebhatu S.B,(2007), "Values-based service quality for sustainable business", Managing Service Quality, Vol.17 ,No.4, pp. 385- 403 
[6] Ghalavandi, Hassan; Beheshtirad, Roghayeh \& Ghalei, Ali Reza (2012), studying service quality in Urumyeh University by SERVQUAL model, Management and Development Process, vo. 3, pp. $49-66$

[7] Hassan Hussieni, Mira \& Ghaderi, Somayeh (2010), affecting factors on banking service quality, Commercial Management Outlook Journal, vol. 3, pp. 89 - 115

[8] Kang, Gi-Du,(2006), "The hierarchical structure of service quality: integration of technical and functional quality", Managing Service Quality,Vol.16, No.1, pp.37-50

[9] Kang, Gi-Du and James, Jeffrey,(2004), "Service quality dimensions: an examination of Gro“nroos's service quality model”, Managing Service Quality, Volume 14, Number 4, pp. 266-277

[10] Lagrosen, Stefan and Lagrosen, Yvonne,(2003), "Management of service quality - differences in values, practices and outcomes", Managing Service Quality, Volume 13, Number 5 , , pp.370-381

[11] Lagrosen, Stefan \& Lagrosen, Yvonne,(2007), “ Exploring service quality in the health and fitness industry”, Managing Service Quality,Vol.17,No.1, pp.41-53

[12] Mirghafouri, Seyed Habibollah \& Zare Ahmadabadi, Habib (2007), analyzing service quality of clinics by using SERVQUAL model, Medical and Health/Treatment Service Journal, Yazd Medical University, vol. 2, pp. 84 - 92

[13] Moradi, Hadi \& Hemati, Amin (2010), measuring customers' satisfaction of service quality by using CANO - SERVQUAL model, $2^{\text {nd }}$ International Conference on Financial Service Marketing

[14] Rajabipour, Ali Reza \& RAjabipour, Batool (2010), using gap analysis model to vassess the quality of library services, a report from Yazd Medical University, Ketab Quarterly, pp. 60 - 69

[15] Skaran, Uma (2013), research methods in management, translated by Mohammad Saebi and Mahmood Shirazi, Public Administration Training Center, $12^{\text {th }}$ edition

[16] Voon , Boo Ho,(2006), "Linking a service-driven market orientation to service quality" ,managing service quality ,vol. 16,n0 6 ,pp 595-619

[17] Yazdani, Hamid Reza (20120, devising a model to measure HR value chain in SAIPA Industrial Group, doctoral dissertation, Management School, University of Tehran

[18] Yang, Ching-Chow,(2003), "Establishment and applications of the integrated model of service quality measurement", Managing Service Quality, Volume 13 , Number 4 , pp.310324

[19] Zahedi, Sakineh (2011), an income on using SERVQUAL model in assessing academic training services; case study: Shahid Beheshti Computer and Power Engineering University, the $5^{\text {th }}$ International Conference on Quality in Tehran University (Technical School)

[20] Ziviar, Farzad; Ziayi, Mohammad Sadegh \& Nargesian, Jawad (2011), studying affecting factors on customer satisfaction by using SERVQUAL model, Modern Marketing Research Quarterly, vo. 3 , pp. $173-186$ 